Ustynova I., Kuzio Ju.

UDC 340.336.025:005(045)

I. Ustynova,

$\mathrm{PhD}$ in Law, Associate Professor

Ju. Kuzio,

Student

\title{
ISSUES ON IMPROVING FINANCIAL CONTROL AS A FORM OF PUBLIC ACTIVITIES
}

\author{
National Aviation University \\ Kosmonavta Komarova Avenue, 1, 03680, Kyiv, Ukraine \\ E-mail:kafedra92@ukr.net
}

\begin{abstract}
Purpose: the improvement of state financial control organization should be ensured by the activity of all organizations, which are part of the state monitoring system at all levels of governance. Financial monitoring in Ukraine is a complex institution in the state monitoring system that provides public management and ensures statehood. Present financial state lacks control and central executive bodies and local selfgovernment are responsible for control, ensuring stability and avoidance of budget legislation violations. We outlined the drawbacks in legal regulations of financial monitoring practices. Methods of research: in the work used analytical, described the methodological basis of the research is such methods as general scientific and specially legal methods. The use of a descriptive method made it possible to characterize the overall system of financial control. Using the formal legal method, the forms of application of financial control measures were analyzed. The system method and the analysis method were also applied to determine the practical component of the results of the financial control measures. Results: the issue of financial monitoring is widely discussed in modern doctrine developments in the field of law and public administration. Financial monitoring system is regarded as an institution of financial law. Present-day state growth raises such fundamental question as governance improving which primary function is to monitor and control. The state cannot function properly and develop without well-organized control system over the production, distribution and redistribution of the social product and over other spheres of social life. Control is an integral part of the society growth, and financial control at the present stage is the basic element of ensuring public activity. Discussion: in modern doctrinal developments in the field of law and public administration, the topic of financial control has been developed quite broadly. Financial control is regarded as an institution of financial law. Although there are points of view that this is part of public administration activities, one cannot disagree.
\end{abstract}

Keywords: financial control; monitoring; governance; public administration; financial authorities; forms of public administration; International Organization of Supreme Audit Institutions.

Formulation of the problem. Present-day state growth raises such fundamental question as governance improving which primary function is to monitor and control. The state cannot function properly and develop without well-organized control system over the production, distribution and redistribution of the social product and over other spheres of social life. Control is an integral part of the society growth, and financial control at the present stage is the basic element of ensuring public activity.

Analysis of recent research and publication. Many scientists dedicated their works to the unveiling the nature of such question as «control» (L.A. Savchenko, I.P. Ustinova, V.M. Gorshenova, O.G. Lukyanova, V.Y. Luchina, P.E. Nedbayla, V.M. Protasova， V.D. Sorokina， V.I. Tertishnikov, O.V. Fatkhutdinova, M.S. Shakaryan, I.B. Shakhov, 
S.O. Shokhin, M.T. Belukhi, I.A. Belobzhetsky, F.F. Butyntsa, L.M. Kramarovsky, M.M. Rovinsky, B.F. Usacha, L.K. Tsarovaet al.).

Problems not resolved before. The democratization of Ukrainian society is an urgent need for the historic moment of Ukraine's development. These processes provide for the protection of financially sound risks. Financial control is such a factor, so awareness of the regulation of this institution is an urgent matter and one that requires ongoing study.

Goal. To analyze present state of organization and implementation of financial control as a form of public activities and decide on the legislative regulation of a mentioned institute.

Presentation of the main material. Before analyzing the concept «financial control», let us consider the concept «public administration». Generally, the term «administration» stands for the activities of directing someone or something. In general, administration is aimed impact on a complex system. Public administration, as an independent type of public activity, should be viewed as a system of state power executiveadministrative elements that regulates economic, socio-cultural and administrative-political spheres. Concept «public management» represents an integrated mechanism, subsystems and elements and priorities of political sphere, normative regulation, state or local self-government financed procedures, centralized and decentralized organizational and managerial structures and their staff, who are responsible for administration in a particular field of public relations at national, subnational and local levels. The definition of «public administration» is under the study, as this concept mainly identified with government but not as separate unit. In the narrow sense, public administration is seen as a professional activity of civil servants, which includes all activities aimed at implementing government decisions, as an interdisciplinary academic field, based on the theory and concepts of economics, political science, sociology, administrative law, management. In the broad sense, public administration is understood as whole system of administrative institutions with the hierarchy of power, through which the responsibility for the implementation of state decisions goes down from above [1, p. 50-51]. Thus, public administration includes public and state administration, and constitutes the unity of institutions and executive bodies that implement government decisions.

The forms of public administration are defined as the outer side of their functioning, that is, the totality of its homogeneous actions, which are implemented within certain organizational frameworks defined by law. In other words, forms of public administration are homogeneous activities of public authorities through which their functions are realized.

In our opinion, it is obvious to distinguish five main forms of legal activity of public authorities: constituent, law-making, law-enforcement, interpretative and control-supervisory.

- Law-making - the activity on creating new legal rules, change them and repeal them.

- Law-enforcement is an activity which helps to provide «the continuity of the implementation process in regulatory legal provisions and ensures assigning subjective rights to some participants in the relationship and entrusting them with other relevant legal obligations or by resolving questions on the consequences of legal disputes and offenses as well as bringing those responsible to justice». Law enforcement types are law empowerment and law enforcement activities.

- Control - «a system of monitoring and checking the process of functioning of the object with the aim to correct its deviation from the specified parameters».

- Constituent - aimed at structural transformations in the state apparatus and the social system.

- Interpretative - «complex, multifaceted, permeating through all the basic forms system of creating and implementing the law with the aim to detect and clarify the content and purpose of the rules of law».

One of the most important functions of state administration is state financial control [2, p. 66]. In a broad sense, financial control is one of the financial activities of the state aimed at verifying entities of all forms of ownership via implementation of control methods established by the legislation to identify deficiencies in the financial statements of enterprises, institutions, organizations, distribution and use of funds.

First of all, it should be noted that the system of financial control includes all entities of the state and 
social sectors of the economy, including parliament [8]. Accounting Institutions, Government, Ministries, State Committees, Budgetary Institutions, Government Organizations and Funds.

Bodies responsible for implementing the state policy in the sphere of financial control are the State Audit Office of Ukraine and the Accounting Chamber of Ukraine. The State Audit Office of Ukraine is a body of financial control of the executive power and obeys to the Cabinet of Ministers of Ukraine. The main task of the State Audit Service is to develop proposals for improving financial control provided by the institution. At the same time, Accounting Chamber of Ukraine obeys to Verkhovna Rada of Ukraine and controls implementation of state expenditure financing.

The objects of state financial control are budgetary enterprises, institutions and organizations, financed enterprises or enterprises that partially use budgetary financial resources, as well as financial relations and proper budgetary funds and state property, financed by state or local budgets [3, p. 32].

Financial management consists of two components. The first component is financial management and control as the head of certain systems, i.e. the internal control with the task to outline the procedure, rules, responsibilities and responsibilities of each management, mainly the CEO and the results or outcomes [4, p. 18]. The second component of government financial control is internal audit, which provides assurances and pieces of advice, and helps to improve management efficiency.

According to scientists, the main goals of financial control are: compliance with the rules of accounting and financial reporting; observance of social guarantees of employees; adherence to pricing and tariff standards; observance of payment discipline; preventing fraudulent financial transactions and money laundering; prevention of misuse and ineffective use of public funds; adherence to the procedures and order of public and municipal procurement $[4, \mathrm{p} .16]$; prevention of inappropriate and inefficient use of state and communal property; prevent the misapplication of government credits and government guaranteed loans.
Among above-mentioned practices it is possible to distinguish problems and shortcomings of the state financial control:

1. Continuous increase in the number of detected illegal and non-targeted expenditures, lack of funds and material assets, which indicates a certain cancellation of financial discipline at the level of budgetary institutions and organizations, and indicates that economic mechanism of management is imperfect and contains lot of weak sides, which contributes to committing crimes;

2. The fines imposed by law are much less than the amount of budget funds that the state loses due to abuse of responsible officials;

3. Insufficient interaction of the State Audit Service of Ukraine with law enforcement and judicial authorities (delaying the courts with consideration of cases, unjustified release of offenders, untimely informing the SCAS authorities on transferring to the executive bodies as to bringing offenders to responsibilities.

Among listed questions, there is also the problem of the lack of systematic control, i.e. the correspondence of the previous, current and subsequent controls. Currently, State Audit Office financial control is punitive and educational, but not preventive in case of fiscal discipline and abuses in the financial and budgetary sphere. So, one of the ways to improve financial control is to increase the effectiveness of the current control by the Treasury in coordination with the executive authorities and the State Fiscal Service [5, p. 27-28]. We stick to the position that involving of the State Audit Office bodies to control the stages of budget forming and expenditures and the State Fiscal Service to control the financial resources formation of budgetary institutions will eliminate significant drawback.

Another issue under the question is the lack of a united legislative definition of economic essence and control procedures in the system of activity of public sector bodies. To identify the drawbacks in the system of public financial control it is necessary to: observe the international state and regional principles of financial control; implement preventive forms of state financial control in the work of controlling entities [3, p. 33]; organize the internal auditing in budgetary institutions and organizations; use of riskoriented approach in the selection of objects of audit 
in budgetary enterprises, institutions, organizations and enterprises using budgetary financial resources or state property.

A topical issue is the development of external audit. There are already some prepared results. The priorities for the development of the external audit are the implementation of the standards and techniques of the International Organization of Supreme Audit Institutions (INTOSAI). INTOSAI is an autonomous, independent and non-political organization with special advisory status at the Economic and Social Council (ECOSOC) at the United Nations (UN). INTOSAI gives auditors the opportunity to share common interest information, information on current audit practices and the use of professional standards and best methodologies all over the world [6, p. 122]. The Accounting Chamber works in the following main international cooperation areas:

- to develop bilateral and multilateral cooperation with Supreme Audit Institutions of foreign countries;

- to cooperate with the European Organization of Supreme Audit Institutions (EUROSAI) and the International Organization of Supreme Audit Institutions (INTOSAI);

- to ensure the EUROSAI Working Group implementation on the audit of funds allocated for the prevention and avoiding the problems under the Accounting Chamber monitoring;

- to participate in EUROSAI Working Groups and Task Force (Environmental Audit; Information Technology and Municipal Audit);

- to participate in INTOSAI Working Groups (Environmental Audit; Public Debt; AntiCorruption and Money Laundering);

- to participate in the work of other regional associations of Supreme Audit Institutions;

- to cooperate with international organizations and to participate in international technical assistance projects and programs;

- to participate in the Accounting Chamber in audits of programs financed by the European Union;

- to organize and conduct international coordinated audits with the participation of members of the Working Group on the Audit of Funds Allocated for Disaster Prevention and Elimination.
An integral part of the Accounting Chamber's international cooperation is the conduct of international coordinated audits, with the involvement of several SAI's. Since 2005 the Accounting Chamber has participated in a number of international coordinated concurrent audits, as evidenced by the relevant reports on their results [7]. The Auditors of the Accounting Chamber are included in the Group of Auditors for the three Border Cooperation Programs of the European Neighborhood and Partnership Instrument (BCP of the ENPI).

Conclusion. Therefore, the current state of public finances requires greater control over the spending of budget funds by central executive authorities and local self-government bodies, combating violations of budget legislation. The improvement of the organization of the system of state financial control should be ensured by the activity of all organizations is part of the state control structure at the level of different branches of state power.

\section{References}

1. Savchenko L.A. (2008). Pravovi problemy koordynatsii finansovoho kontroliu: monohrafiia [Legal problems of coordination of financial control: a monograph]. KyMU, Kyiv, Ukraine.

2. Zhernakov M. (2011). Financial control: the essence, the subjects, their rights and responsibilities. Pidpryiemnytstvo, hospodarstvo i pravo. Vol. 3. Pp. 64-66.

3. Esmanov O.M. (2010). Reforming the system of state financial control in Ukraine. Biznesinform. Vol. 12. Pp. 32-34.

4. Stefaniuk I.B. (2011). State financial control: problems of system identification and definition. Finansy Ukrainy. Vol. 3. Pp. 12-19.

5. Buzduhan Ya. (2011). Financial control and legal ways of its implementation. Pidpryiemnytstvo, hospodarstvo i pravo. Vol. 6. Pp. 26-29.

6. Kosova T. (2018). Higher state financial control in the condition of eurointegration of Ukraine. Zovnishnia torgivlia: ekonomika, finansy, pravo. Vol. 1. Pp. 121-129.

7. The Accounting Chamber. (2019). International cooperation. Available at: https://rp.gov.ua/IntCooperation/General/ (Accessed 10 Dec 2019).

8. Verkhovna Rada of Ukraine. (2019). The Law 
Ustynova I., Kuzio Ju.

of Ukraine «Basic principles of state financial control of Ukraine». Available at: https://zakon.rada.gov.ua/ laws/show/293912(Accessed 12 Dec 2019).

\section{Лimepamypa}

1. Савченко Л.А. Правові проблеми координації фінансового контролю: монографія. Київ: КиМУ, 2008. 230 с.

2. Жернаков M. Фінансовий контроль: сутність, суб'єкти, їх права та обов'язки. Підприємниитво, господарство і право. 2011. № 3. C. 64-66.

3. Есманов О.М. Реформування системи державного фінансового контролю в Україні. Бізнесінформ. 2010. № 12. С. 32-34.
4. Стефанюк І.Б. Державний фінансовий контроль: проблеми ідентифікації й визначення системи. Фінанси України. 2011. № 3. С. 12-19.

5. Буздуган Я. Фінансовий контроль і правові шляхи його реалізації. Підприємництво, господарство і право. 2011. № 6. С. 26-29.

6. Косова Т., Шевченко В. Вищий державний фінансовий контроль в умовах євроінтеграції України. Зовнішня торгівля: економіка, фінанси, право. 2018. № 1. С. 121-129.

7. Міжнародне співробітництво. URL: https://rp.gov.ua/IntCooperation/ General/.

8. Про основні засади здійснення державного фінансового контролю в Україні: Закон України від 26 січ. 1993 р. № 2939-XII. Відомості Верховної Ради Украӥни. 1993. № 13. Ст. 110. 
І.П. Устинова, Ю.В. Кузьо

\title{
ДЕЯКІ ПИТАННЯ ЩОДО УДОСКОНАЛЕННЯ ФІНАНСОВОГО КОНТРОЛЮ ЯК ФОРМИ ПУБЛІЧНОЇ ДІЯЛЬНОСТІ
}

\author{
Національний авіаційний університет \\ проспект Космонавта Комарова, 1, 03680, Київ, Україна \\ E-mail: kafedra92@ukr.net
}

\begin{abstract}
Мета: полягає в дослідженні чинного стану організаџї та здійснення фінансового контролю як форми публічної діяльності та висловлення позииії щодо законодавчого регулювання визначеного інституту. Результати: визначено, щзо удосконалення організації системи державного фінансового контролю має бути забезпечене діяльністю всіх організачій, які входять у структуру державного контролю на рівні різних гілок державної влади. Встановлено, щэо фінансовий контроль в Украӥні $\epsilon$ комплексним інститутом в системі публічного адміністрування, який забезпечує публічне управління та забезпечення державності. Запропоновано вважати сучасний стан державних фінансів потребує посилення контролю за витрачанням бюджетних коштів органами иентральної виконавчої влади та місиевого самоврядування, боротьби з порушеннями бюджетного законодавства. Визначені недоліки y правовому регулюванні сучасних практик фінансового контролю. Обговорення: у сучасних доктринальних розробках в галузі права та державного адміністрування тема фінансового контролю розроблена достатньо широко. Фінансовий контроль розглядається як інститут фінансового права. Хоча існують точки зору, що це частина діяльності публічного адміністрування, з чим не можна не погодитися.

На сучасному етапі розвитку країни особливу актуальність набувають питання вдосконалення управління, однією із важливих функцій якого є контроль. Держава не може нормально функціонувати і розвиватися без чітко організованої системи контролю за виробництвом, розподілом і перерозподілом суспільного продукту та іншими сферами суспільного життя в державі. Контроль $\epsilon$ невід'смним елементом надбудови суспільства, $і$ саме фінансовий контроль на сучасному етапі $\epsilon$ базовим елементом забезпечення публічної діяльності.

Ключові слова: фінансовий контроль; державне управління; публічне адміністрування; фінансові органи; форми публічного адміністрування; Міжнародна організація вищих органів фінансового контролю.
\end{abstract}

